Discussion Paper No. 09-015

The Role of Structural Common and Country-Specific Shocks in the Business Cycle Dynamics of the G7 Countries

Atılım Seymen and Marcus Kappler

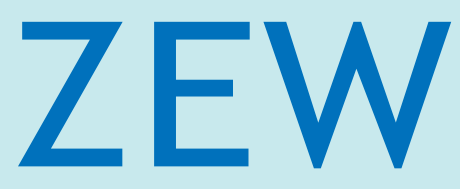

Zentrum für Europäische Wirtschaftsforschung $\mathrm{GmbH}$

Centre for European

Economic Research 
Discussion Paper No. 09-015

\title{
The Role of Structural Common and Country-Specific Shocks in the Business Cycle Dynamics of the $\mathbf{G} 7$ Countries
}

\author{
Atılım Seymen and Marcus Kappler
}

Download this ZEW Discussion Paper from our ftp server:

ftp://ftp.zew.de/pub/zew-docs/dp/dp09015.pdf

Die Discussion Papers dienen einer möglichst schnellen Verbreitung von neueren Forschungsarbeiten des ZEW. Die Beiträge liegen in alleiniger Verantwortung der Autoren und stellen nicht notwendigerweise die Meinung des ZEW dar.

Discussion Papers are intended to make results of ZEW research promptly available to other economists in order to encourage discussion and suggestions for revisions. The authors are solely responsible for the contents which do not necessarily represent the opinion of the ZEW. 


\section{Non-Technical Summary}

The study analyses business cycles of the G7 countries in a structural vector autoregression (SVAR) framework with common factors. A multitude of studies which investigate the driving forces of international business cycles distinguish between common and country-specific shocks, while the identified shocks are not given an economic interpretation. The main advantage of our approach vis-à-vis other empirical approaches is that we consider three types of structural shocks -supply, demand and nominal- that contain (unobserved) common and country-specific elements. Such a modelling approach is in line with a class of theoretical international business cycle models that trace international linkages back to common exogenous shocks.

We first establish that output cycles of the G7 countries have generally been highly correlated, but a recent increase in the cycle synchronisation is not observed. Nominal interest rate growth is found to be moderately correlated in the G7 group, and since the mid-1990s a gradual increase in synchronisation took place. Inflation growth, however, has always been a rather country-specific phenomenon according to our findings.

In order to assess the similarity of the shock propagation mechanisms in the G7 countries, we compute correlations that would have been observed if the countries were subject to common shocks only. We find that we would generally observe much higher correlations of the cyclical measures if only common shocks occurred or if common shocks had a larger share in the variance of the cycles. Japan is an exception to this rule.

Common supply shocks are the only important contributor to output fluctuations within the class of common shocks and the main driving force of synchronisation. Country-specific nominal shocks contribute to the output cycle variance only in Canada, Italy and the US, and country-specific demand shocks only in the US. The weights of nominal and demand shocks are negligible for all other G7 countries. The G7 countries do not differ much in terms of shock propagation with respect to inflation growth, but they are subject to large asymmetric shocks. This explains the low correlations of inflation growth in the G7 group. The total share of common shocks is generally relatively high in the G7 countries' nominal interest rate growth, which explains the strong correlation among the G7 countries' nominal interest rate growth. 


\section{Nicht-technische Zusammenfassung}

Die Studie analysiert Konjunkturzyklen der G7 Länder in einem strukturellen vektorautoregressiven Modell mit gemeinsamen Faktoren. Eine Vielzahl von Studien, welche die Quellen von internationalen Konjunkturzyklen untersuchen, unterscheiden zwischen allgemeinen und länderspezifischen Schocks, wobei identifizierte Schocks nicht ökonomisch interpretiert werden. Die Besonderheit unseres Ansatzes im Vergleich zu anderen empirischen Arbeiten liegt darin, dass wir drei Typen von strukturellen Schocks (angebotsseitig, nachfrageseitig und nominal) berücksichtigen, die (unbeobachtbare) gemeinsame und länderspezifische Elemente enthalten. Ein solcher Modellierungsansatz steht im Einklang mit einer Klasse von theoretischen Konjunkturmodellen, die internationale Verbindungen auf gemeinsame exogene Schocks zurückführen.

Wir stellen fest, dass die Outputzyklen der G7 Länder zwar im Allgemeinen stark korreliert sind, aber ein neuerlicher Anstieg in der Zyklensynchronisation nicht beobachtet werden kann. Das Wachstum der Nominalzinssätze ist in der Gruppe der G7 Länder mäßig korreliert und seit Mitte der 90er hat eine allmähliche Synchronisation stattgefunden. Allerdings ist die Entwicklung der Inflation nach unseren Ergebnissen schon immer eher ein länderspezifisches Phänomen gewesen.

Um die Ähnlichkeit der Schockfortpflanzungsmechanismen der G7 Länder abschätzen zu können, berechnen wir Korrelationen, die sich ergeben würden, wenn die Länder nur gemeinsamen Schocks ausgesetzt wären. Wir finden, dass wir im Allgemeinen viel höhere Korrelationen der konjunkturabhängigen Maße beobachten würden, wenn nur gemeinsame Schocks auftreten oder wenn gemeinsame Schocks einen größeren Anteil an der Varianz der Zyklen besitzen. Japan ist eine Ausnahme von dieser Regel.

Gemeinsame Angebotsschocks leisten innerhalb der Klasse der gemeinsamen Schocks als einzige einen wichtigen Beitrag zur Outputfluktuation und stellen die Hauptantriebskraft der Synchronisation dar. Länderspezifische nominale Schocks tragen nur in Kanada, Italien und den USA zur Varianz der Outputschwankungen bei und länderspezifische Nachfrageschocks nur in den USA. Die Bedeutung von nominalen Schocks und Nachfrageschocks ist für alle anderen G7 Länder vernachlässigbar. Die G7 Länder unterscheiden sich nicht wesentlich in der Dauer der Schockausbreitung bezüglich des Inflationswachstums, aber sie sind großen 
asymmetrischen Schocks ausgesetzt. Das erklärt die schwache Korrelation des Inflationswachstums innerhalb der G7 Gruppe. Der gesamte Anteil gemeinsamer Schocks ist im Wachstum der nominalen Zinssätze generell für die G7 Länder relativ hoch, was die starke Korrelation dieser Größe zwischen den G7 Ländern erklärt. 


\title{
The Role of Structural Common and Country-Specific Shocks in the Business Cycle Dynamics of the G7 Countries*
}

\author{
Atılım Seymen ${ }^{\dagger}$ \\ Marcus Kappler $\ddagger$
}

\section{March 2009}

\begin{abstract}
The study analyses the business cycles of the G7 countries in a structural vector autoregression (SVAR) framework comprising output, nominal interest rate and inflation. Common and countryspecific supply, demand and nominal shocks of each G7 country are identified, and the corresponding shock propagation channels are computed. We establish the statistical properties of the cyclical fluctuations and investigate the role of each structural common and country-specific shock in the cyclical fluctuations of the variables of interest as well as the business cycle co-movement in the G7 group of countries.
\end{abstract}

\section{JEL classification: C32, E32}

Keywords: International Business Cycles, Common and Country-Specific Structural Shocks, Structural Vector Autoregression Models

*The paper has partly been presented to the European Commission Bureau of European Policy Advisers (BEPA) within a "Study on Economic Integration and Business Cycle Synchronisation" with the reference number BEPA-01/2007-PO. Financial support by BEPA is gratefully acknowledged.

Earlier versions have been presented at: the Macro-Finance Brown Bag Seminar at the Centre for European Economic Research in September 2008; the 5th Eurostat Colloquium on "Modern Tools for Business Cycle Analysis", jointly organised by Eurostat and the European University Institute in Luxembourg in October 2008; and the "Workshop on Methods and Applications for Macroeconomics and Finance" held at the Ege University in Izmir in October 2008; "Macroeconometric Workshop" at the German Institute for Economic Research in Berlin in November 2008. We thank the participants for their comments and suggestions. In particular, we are grateful to Tara Sinclair for her useful feedback. Any errors are our own.

$\dagger$ Address: Centre for European Economic Research (ZEW), P.O. Box 103443, D-68304 Mannheim, Germany. E-mail: seymen@zew.de

${ }^{\ddagger}$ Address: Centre for European Economic Research (ZEW), P.O. Box 103443, D-68304 Mannheim, Germany. E-mail: kappler@zew.de 


\section{Introduction}

This study analyses the business cycles of the G7 countries in a structural vector autoregression (SVAR) framework with common factors. Our main interest lies in assessing the extent to which the business cycle co-movement in the G7 group is driven by structural common shocks. A multitude of studies, which investigate the driving forces of international business cycles, distinguish between common and country-specific shocks, while such shocks are rarely given an economic intepretation. ${ }^{1}$ In this study, we identify three types of structural common and country-specific shocks -supply, demand and nominal- and hence distinguish between more than common and country-specific shocks only.

We start our investigation by establishing the statistical properties of the G7 countries' cycles of output, inflation and nominal interest rate. Our main interest lies in inferring (i) the degree of co-movement of the G7 countries' cycles and (ii) whether there has been a change in the co-movement patterns over time. The first question is investigated by means of the simple correlation coefficient as the measure of co-movement, while the second question is addressed by computing mean and variance of correlations over 6-year rolling windows. A higher mean accompanied by a lower standard deviation implies an increase in business cycle synchronisation among the G7 countries. After establishing the statistical properties of the G7 countries' cycles, we decompose the variances of each country's cycles with respect to the common and country-specific components of supply, demand and nominal shocks using our empirical model. We are particularly interested in determining (i) which structural shocks drive or dampen international cyclical co-movements of output, inflation and nominal interest rate; (ii) which types of structural shocks drive the cyclical fluctuations of the individual countries; and (iii) the share of common shocks in cyclical fluctuations.

Many studies investigating the international business cycles in the existing SVAR literature check the correlation of the estimated structural shocks of different countries in order to assess the degree of international business cycle synchronisation. ${ }^{2}$ This approach alone

\footnotetext{
${ }^{1}$ Stock and Watson (2005) and Canova et al. (2007) estimate, for example, common shocks and countryspecific shocks with spillover effects within the G7 group. Perez et al. (2006) identify US, EU15 and countryspecific shocks. Crucini et al. (2008) model common G7, nation-specific and idiosyncratic factors. While following different approaches to identification, none of these studies pursue a structural identification. Clearly, this list is far from being exhaustive, but can be extented.

${ }^{2}$ See, among others, Artis (2000), Bayoumi and Eichengreen (1992), Chamie et al. (1994), Fidrmuc and
} 
suffers from at least two drawbacks. First, it does not consider the country-specific and common components of structural shocks explicitly. Second, it ignores the role of the transmission mechanism. Yet, structural shocks constitute only one aspect, while information on the shock propagation mechanism is also needed for a proper understanding of international business cycles. Structural shocks of two countries may, for instance, be highly correlated, but the response of macroeconomic variables to these shocks may differ. Our analysis of the business cycle dynamics of the G7 countries addresses both of these issues. We compute counterfactual correlations and carry out variance decompositions of each G7 country's cycles.

Different approaches have been developed in the macroeconometric literature for estimating country-specific and common shocks as well as their propagation. ${ }^{3}$ We follow Chamie et al. (1994) and Xu (2006) who first estimate the structural shocks of the individual countries within a country-specific VAR model of each country in their sample, and then compute the common and country-specific components of those shocks with the Kalmanfilter technique, whereby the components are modelled as unobservable states. However, we deviate from the procedure by estimating a seemingly unrelated regression (SUR) system of country-specific VAR models for the G7 countries to increase the estimation efficiency and to address the international linkages. Our country-specific VAR models comprise output, real interest rate and inflation. The error terms corresponding to these variables are assumed to be linear combinations of supply, demand and nominal shocks.

There are two extreme situations which can potentially explain a far-from-perfect comovement of two countries' cycles: (i) either both countries are subject to common shocks only, but their shock propagation mechanisms differ substantially; or (ii) countries exhibit similar shock propagation, but they are subject to asymmetric shocks only. The reality is probably somewhere in between. In order to assess the similarity of the shock propagation mechanisms in the G7 countries, we compute counterfactual correlations -i.e. correlations

Korhonen (2003), Frenkel and Nickel (2005) and Xu (2006).

${ }^{3}$ We refer the reader to Stock and Watson (2005) for a brief review of some of these approaches, which include identifying a world (G7) shock in a univariate time series model of the world and estimating parametric or nonparametric dynamic factor models. Stock and Watson (2005) discuss the strengths and weaknesses of these approaches and provide a list of studies employing them. Stock and Watson (2005) themselves work with a factor-structural VAR model for the analysis of international business cycle dynamics. 
that would have been observed if the countries were subject to common shocks only and no country-specific shocks took place. High counterfactual correlations with respect to common shocks point to the similarity of dynamic response mechanisms in the G7 countries. The weight of asymmetric shocks in the cycles of the G7 countries are assessed with variance decomposition.

The following section presents the econometric methodology used for the analysis of the properties of business cycles. Section 3 starts with a descriptive analysis of the cycles of the G7 countries and presents the results of our econometric analysis. Section 4 concludes.

\section{Econometric Methodology}

Several frameworks have been proposed in macroeconometric studies that investigate international business cycles, and two characteristics are common to most of them: they typically investigate the output cycles and do not attribute the identified shocks an economic interpretation. Our empirical framework does, however, not bear these characteristics. We investigate the properties of inflation and nominal interest rate growth in addition to output cycles and analyse the impact of common and country-specific supply, demand and nominal shocks for each country. The structural shocks are identified by allowing interactions among output, real interest rate and inflation growth in each G7 country. Yet, including more variables as well as estimating structural shocks comes at the cost of restricting direct interactions among the variables across the G7 countries: countries in our empirical model are allowed to interact through exogenous shocks only. On the other hand, although our empirical framework is simple, it is in line with a class of theoretical models as argued below. Since our approach provides advantages and disadvantages vis-à-vis other empirical frameworks, it brings useful insights into the nature of the dynamics of business cycles in the G7 group. We compare our findings with other studies' findings in our concluding remarks.

Our empirical analysis is based on $K$-dimensional reduced-form country-specific VARs given by

$$
\Delta X_{i, t}=\nu_{i}+A_{i, 1} \Delta X_{i, t-1}+\cdots+A_{i, p} \Delta X_{i, t-p}+u_{i, t}
$$

for country $i$, where $X_{i, t}$ is the vector of endogenous variables, $\Delta$ is the difference operator 
such that $\Delta X_{i, t}=X_{i, t}-X_{i, t-1}, \nu_{i}$ is the constant vector, $A_{i, j}$ is the $j^{\text {th }}$ VAR coefficient matrix of country $i$ for $i=1, \ldots, 7$ and $j=1, \ldots, p, p$ is the lag order of the VAR, and $u_{i, t}$ denote linear combinations of structural innovations. We estimate the VAR coefficient matrices as well as the innovations within a SUR framework for the G7 countries. Let the structural moving average representation of (1) be

$$
\Delta X_{i, t}=\mu_{i}+C_{i}(L) \varepsilon_{i, t}
$$

where $L$ is the conventional lag operator, $C_{i}(L)=\sum_{j=0}^{\infty} C_{i, j} L^{j}, \mu_{i}$ is the constant vector, and $u_{i, t}=B \varepsilon_{i, t} . \quad \varepsilon_{i, t}$ are typically given an economic interpretation through imposition of some restrictions on the elements of the $K \times K$ matrix $B$ with $K^{2}$ unknown elements.

\subsection{Identification of Structural Shocks}

The identification procedure that we employ for determining the matrix $B$ is the one with long-run restrictions introduced to the macroeconometric literature by Blanchard and Quah (1989). Each country-specific VAR model comprises the log of output, $y_{i, t}$, which is represented here by the real GDP, the real interest rate, $R_{i, t}-\pi_{i, t}$, and the inflation rate, $\pi_{i, t}$, of the corresponding country. Note that such a model includes the nominal interest rate, $R_{i, t}$, indirectly, which is the sum of the real interest rate and the inflation rate by construction.

The dynamic multipliers and the structural shocks contained, respectively, in $C_{i}(L)$ and $\varepsilon_{i, t}$ can be easily computed when the matrix $B$ is identified. In the case of a VAR model with three variables, the identification of $B$ follows from $K(K+1) / 2=6$ restrictions coming from the assumption of a covariance matrix of $\varepsilon_{i, t}$ of the form $\Sigma_{\varepsilon}=I_{K}$, where $I_{K}$ stands for the $K \times K$ identity matrix. Furthermore, $K(K-1) / 2=3$ restrictions follow from the assumption that the structural matrix of the long-run multipliers $C_{i}(1)$ is lower triangular:

$$
C_{i}(1)=\left[\begin{array}{ccc}
c_{i, 11} & 0 & 0 \\
c_{i, 21} & c_{i, 22} & 0 \\
c_{i, 31} & c_{i, 32} & c_{i, 33}
\end{array}\right]
$$

Thus, the first shock in this system is called a supply shock in line with the identification 
scheme of Blanchard and Quah (1989), since this is the only shock that can affect the level of output in the long run. This restriction is consistent with the majority of theoretical macroeconomic models which imply that output is determined only by supply-side shocks in the long run. The second shock affects the real interest rate in the long run alongside the supply shock, but not the output, and is labelled as a demand shock. The idea behind this restriction is that the demand shock may affect the composition of output in the long run, but not its level. The motivation for this assumption follows, among others, from the study of King et al. (1991), whose arguments and empirical findings suggest that long-run changes in the real interest rate can affect the consumption-output and the investment-output ratios, but not the level of output. Moreover, a strand of the macroeconomic literature also suggests that long-run real interest rate movements can be affected by government debt, hence also by fiscal expenditures, which are also typically seen as demand boosting measures, however, without a major long-run impact on production possibilities and output. The last shock is called a nominal shock, which can affect only the nominal variables in the model -the inflation rate and the nominal interest rate- in the long run, but not the real variables, output and real interest rate. This restriction is common to theoretical models which investigate the long run. Such theoretical models do typically not comprise money and prices, since monetary phenomena should not be relevant for real variables in the long run according to the standard theory. Note, however, that our model does not restrict the short-run effects of nominal shocks on the real variables -the output and the real interest rate.

\subsection{Estimation of Common and Country-Specific Components}

The estimation of the common and country-specific components of the supply, demand and nominal shocks is conducted as by Chamie et al. (1994). The procedure starts with estimating a SVAR model for each G7 country as described above. In the second step, the estimated shocks of all countries are collected in a state-space model, where each country's structural shocks are assumed to comprise an unobserved component common to all countries and an unobserved country-specific component, which are orthogonal to each other by construction. Formally, the $j^{\text {th }}$ block for $j=1,2,3$-with respect to the $j^{\text {th }}$ structural shock- 
of the measurement equation reads

$$
\left[\begin{array}{c}
\varepsilon_{1, t}^{j} \\
\vdots \\
\varepsilon_{7, t}^{j}
\end{array}\right]=\left[\begin{array}{c}
\alpha_{10}^{j} \\
\vdots \\
\alpha_{70}^{j}
\end{array}\right] \xi_{0 t}^{j}+\left[\begin{array}{c}
\xi_{1 t}^{j} \\
\vdots \\
\xi_{7 t}^{j}
\end{array}\right]
$$

where $\alpha_{i 0}^{j}$ is the loading for the $i^{\text {th }}$ country, corresponding to the common factor of the $j^{\text {th }}$ structural shock, $\xi_{0 t}^{j}$ is the common factor for the $j^{\text {th }}$ structural shock, and $\xi_{i t}^{j}$ is the country-specific component of the $j^{\text {th }}$ structural shock for the $i^{\text {th }}$ country. Hence, $\alpha_{i 0}^{j} \xi_{0 t}^{j}$ gives the common component of the $j^{\text {th }}$ structural shock for the $i^{\text {th }}$ country. Both unobservable components are modeled as white noise errors due to the assumption of no autocorrelation and no cross-correlation of the structural shocks and their zero-mean property.

The parameters of the system and the unobserved common components are estimated via Maximum Likelihood and the Kalman filter. Since our state equations comprise only white noise errors, the fixed-interval smoother and the one-step-ahead estimates of the states coincide. Therefore, our inference about the system's states does not depend on the chosen smoothing algorithm of the Kalman filter recursion.

\subsection{Model Dynamics}

Finally, the estimated coefficients of the state-space model are fed back to the original country-specific SVAR models, represented by (2):

$$
\left[\begin{array}{c}
\Delta y_{i, t} \\
\Delta\left(R_{i, t}-\pi_{i, t}\right) \\
\Delta \pi_{i, t}
\end{array}\right]=\mu_{i}+C_{i}(L)\left[\begin{array}{cccccc}
\alpha_{i 0}^{1} & 1 & 0 & 0 & 0 & 0 \\
0 & 0 & \alpha_{i 0}^{2} & 1 & 0 & 0 \\
0 & 0 & 0 & 0 & \alpha_{i 0}^{3} & 1
\end{array}\right]\left[\begin{array}{c}
\xi_{0 t}^{1} \\
\xi_{i t}^{1} \\
\xi_{0 t}^{2} \\
\xi_{i t}^{2} \\
\xi_{0 t}^{3} \\
\xi_{i t}^{3}
\end{array}\right]
$$

The representation in (4) allows us to compute the impulse response functions and historical decompositions of the model variables with respect to each common and country-specific 
structural shock. Using (4), a variable of the model, say $x$ of country $i$ at period $t$, can be written as

$$
x_{i, t}=x_{i, t, \xi_{0}^{1}}+x_{i, t, \xi_{i}^{1}}+x_{i, t, \xi_{0}^{2}}+x_{i, t, \xi_{i}^{2}}+x_{i, t, \xi_{0}^{3}}+x_{i, t, \xi_{i}^{3}}
$$

where $x_{i, t, \xi_{0}^{j}}$ and $x_{i, t, \xi_{i}^{j}}$ are the values of $x_{i, t}$ if only the common or the country-specific component of the $j^{\text {th }}$ shock had taken place at and before period $t$, respectively. This linear decomposition allows us to compute the variance of $x_{i, t}$ as a sum of the covariances of its sub-components with $x_{i, t}$ itself:

$$
\operatorname{var}\left(x_{i, t}\right)=\operatorname{cov}\left(x_{i, t}, x_{i, t, \xi_{0}^{1}}\right)+\operatorname{cov}\left(x_{i, t}, x_{i, t, \xi_{i}^{1}}\right)+\cdots+\operatorname{cov}\left(x_{i, t}, x_{i, t, \xi_{0}^{3}}\right) .
$$

Since (6) is a statistical identity and holds exactly, $\operatorname{cov}\left(x_{i, t}, x_{i, t, \xi_{k}^{j}}\right) / \operatorname{var}\left(x_{i, t}\right)$ for $k=0, i$ gives an estimate of the share of the sub-component with respect to the common or countryspecific structural shock $j$ of $x_{i, t}$ in the total variance of $x_{i, t} \cdot{ }^{4}$ We employ this type of a variance decomposition in order to estimate the shares of the structural shocks over the entire sample as well as over 6-year rolling windows below. The latter allows us to compute the changing role of shocks throughout our sample period.

\subsection{Theoretical Background}

Many theoretical international business cycle models connect different economies through exogenous processes. For instance, in a typical two-country model, both countries are assumed to show a similar structure with different parameter values. The models considered by Backus et al. (1992) and Baxter and Crucini (1993) provide a good example. The authors assume that two economies are linked through technology, which is a part of the production function and is modelled as an exogenous process:

$$
\left[\begin{array}{c}
A_{t} \\
A_{t}^{*}
\end{array}\right]=\left[\begin{array}{cc}
\rho_{A} & \rho_{A^{*}} \\
\rho_{A}^{*} & \rho_{A^{*}}^{*}
\end{array}\right]\left[\begin{array}{c}
A_{t-1} \\
A_{t-1}^{*}
\end{array}\right]+\left[\begin{array}{c}
\varepsilon_{t} \\
\varepsilon_{t}^{*}
\end{array}\right],
$$

\footnotetext{
${ }^{4}$ Note that negative "shares" cannot be ruled out a priori in practice. However, a negative share is estimated rarely in this paper, and if at all, its absolute value is very small. Large negative shares would imply that the structural shocks exhibit autocorrelation, i.e. the empirical model is not correctly specified, since it is typically assumed that the structural shocks are not correlated contemporaneously as well as over time, see Seymen (2008).
} 
where $A_{t}$ and $A_{t}^{*}$ stand for the levels of technology in the home and foreign countries, respectively, $\rho$ and $\rho^{*}$ are the coefficients corresponding to the lag of the technology level in the home and foreign countries, respectively, and $\varepsilon_{t}$ and $\varepsilon_{t}^{*}$ are the technology shocks of both countries with a non-zero covariance matrix. Note that other sources of shocks can be easily added to (7). Technology shocks present one element of supply shocks, while other supply phenomena, such as investment-specific technology shocks, depreciation shocks, etc., could also be considered. Demand shocks can be included in the form of preference shocks affecting the consumption or leisure choices of households exogenously, or in the form of shocks related to macroeconomic policy, such as tax shocks, government spending shocks, etc. Finally, nominal shocks could be integrated analogously into a theoterical model that includes money and prices. Our empirical model is assumed to reflect this type of structure in a simple way, where the coefficients corresponding to the lagged level of exogenous processes are embedded in the structural matrix polynomial $C_{i}(L)$ in (2) and (4), and the correlation between the structural shocks of the individual countries is due to the common component as defined by (3).

\section{Empirical Results}

\subsection{The Data}

Analyses of international business cycles usually refer to the cyclical components of the logarithms of real variables, such as output and consumption. In this study, we also consider the nominal side of the economy by looking at the synchronisation of the inflation growth and the nominal interest rate growth in the G7 group. The former variable is of interest in the face of the recent ups and downs in inflation in the world, which is traced back mainly to movements in the oil and commodity prices. Inflation is a relevant variable for monetary policy in the G7 countries, and it is informative to assess the extent to which the quarterly changes in inflation are due to international or country-specific factors. Regarding the latter variable, the real interest rate is an important determinant of international capital flows, and its level is to a large extent determined by the movements of the nominal interest rate. Given that the interest rate is one of the crucial, if not the most crucial, monetary policy 
instruments, investigating the international co-movement properties of its changes is also likely to give a clue as to the extent to which the policy-makers of the G7 countries take into account international factors when setting the interest rates.

In our empirical analysis, we use quarterly data from the OECD Economic Outlook Database. The measure of output is real GDP. The inflation rate is computed based on the GDP deflator. The nominal interest rate is the short-term interest rate. The real interest rate is computed as the difference between the nominal interest rate and the inflation rate. Our data set spans the period from 1971:1-2007:4, including the initial values. The cyclical component of output is computed using the asymmetric filter suggested by Christiano and Fitzgerald (2003), where the business cycle horizon is assumed to be in the time period from 6 to 32 quarters. The cyclical measure for the inflation and the nominal interest rate is the quarterly growth.

\subsection{International Business Cycle Co-movement: Descriptive Analysis}

Table 1 shows that output cycles of the G7 countries have been positively and highly correlated over the entire sample period. ${ }^{5}$ Japanese output cycles have been in general less related to other G7 countries' cycles, excluding Germany. The existence of two cyclically coherent groups - the euro area and the English-speaking countries- in terms of GDP cycles as observed by Stock and Watson (2005) for GDP growth rates cannot be detected. Inflation growth rates show much less coherence, if at all, as can be seen in the second panel of the table. ${ }^{6}$ Whether these results are due to different shock propagation or asymmetric shocks will be discussed below. Nominal interest rate growth -another high frequency variable- of the G7 countries are moderately correlated, but the reported correlations are not as strong as the correlations of the output cycles. Interesting also to note is that, as in the case of output cycles, Japan differs from the other G7 countries to an important extent in terms of

\footnotetext{
${ }^{5}$ The sample period for the reported correlations in Table 1 covers the period from 1972:2-2007:4. Note that we lose five observations when estimating our empirical model: one observation is lost due to firstdifferencing the nonstationary variables and four observations are used as initial observations. Therefore, we have discarded the observations from 1971:1-1972:1 when computing the correlations reported in Table 1 for the sake of comparibility with the results presented in the following sub-sections.

${ }^{6}$ This lack of coherence might be due to the high-frequency nature of growth rates. Therefore, we have repeated our correlation computations with "inflation cycles" based on the Christiano-Fitzgerald filter as in the case of output. The results, not reported here, were quite similar.
} 
nominal interest rate growth.

Figure 1, which shows the mean and standard deviation of correlations of the G7 countries' cyclical fluctuations over a 6-year rolling window, is generally in line with the numbers presented in Table 1: output cycles and nominal interest rate growth have historically also always been more strongly correlated than the inflation growth in the G7 group. A comparison of the correlations of output cycles and nominal interest rate growth shows that the average correlation of the latter variable was relatively low until the mid-1990s, while the average output cycle correlation over a 6-year rolling window in the same period decreased gradually. However, the average correlation started to increase by the mid-1990s for both variables. This increase has nevertheless been reversed abruptly for the output cycles after 2005, whereas the average nominal interest rate growth correlation has continued increasing up to this date. Although a slight increase can be observed on average for the mean correlation of inflation growth after 1990 roughly, that correlation stayed still much lower than the correlation of output cycles and nominal interest rate growth.

An increase in the average correlation over a 6-year rolling window alone can lead to spurious conclusions regarding the changing dynamics of business cycle synchronisation. Only when such an increase is accompanied by a decrease in the corresponding standard deviation, one can surely talk of a stronger international business cycle synchronisation. In this respect, it is interesting to observe that the increases (decreases) in the standard deviation of output cycle correlation illustrated in Figure 1 consistently follow the decreases (increases) in reported mean correlations. It is not possible to say according to these pictures that either an increasing or decreasing business cycle synchronisation has occured in the entire covered sample period. There are, however, episodes of high and low synchronisation. We also establish that the dispersion of correlations of inflation growth and nominal interest rate growth has not changed much through time, i.e., the reported standard deviation has followed a rather stable path. Regarding the nominal interest rate growth, this observation reflects a steady increase in synchronisation since the mid-1990s.

Our empirical model is constructed so that only common G7 shocks can lead to comovements of the G7 countries' cycles. Accordingly, we are interested in two main questions in the following. First, we will investigate which type of structural shock(s) can explain 
the relatively high and positive output cycle and nominal interest rate growth correlations. Second, we will check the extent to which the lack of a strong co-movement in terms of inflation growth has its roots in distinct shock propagation mechanisms or asymmetric shocks across the G7 countries.

\subsection{Specification of the Empirical Model}

Since we are working with quarterly data and different information criteria point to different lag orders for different countries, four lags of the endogenous variables have been included in the VAR estimation of every country for the sake of comparability. Furthermore, it has been assumed that output, real interest rate and inflation are integrated of order 1 in every G7 country and exhibit no cointegration. Statistical tests of cointegration rank have pointed to ambiguous results, depending on the model specification and country considered. We have decided for no cointegration for all countries' models, since this null hypothesis could not be rejected in many cases, and in order to ensure the comparibility of our results.

Table 2 reports the estimated $\alpha$ coefficients of the common components of the structural shocks -supply, demand and nominal- in (3). Almost all coefficients of the G7 countries except Japan are significant at the 5-percent level. The coefficient for Italy corresponding to the common supply shock and the coefficient for the US corresponding to the common nominal shock are significant at the 10-percent level. The estimated coefficients for Japan are low in absolute value and differ significantly from the other G7 countries' estimated coefficients. Important is that all estimated coefficients are positive abstracting from the (insignificantly) estimated coefficient corresponding to the common demand shocks for Japan. This is plausible and implies that the dynamic response of a country to a unit common and a unit country-specific structural shock follows the same direction. ${ }^{7}$

\subsection{International Business Cycle Co-movement: Counterfactual Analysis}

Tables $3 \mathrm{a}$, 3b and $3 \mathrm{c}$ show the counterfactual correlations of output cycles and counterfactual correlations of quarterly inflation growth and nominal interest rate growth of the G7

\footnotetext{
${ }^{7} \mathrm{~A}$ negative coefficient would, on the other hand, imply that the response of a country's variables to a unit, say, common supply and country-specific supply shock of the same type are mirror-inverted.
} 
countries that would have taken place if the G7 countries were subject to common shocks only. $^{8}$ The first three panels of the tables show the counterfactual correlations with respect to common supply, demand and nominal shocks, respectively. The last panel reports the counterfactual correlations if all three common shocks took place in the sample period. Note that the common shocks are by construction the only driving force of international business cycle co-movement in our empirical framework. A high positive counterfactual correlation indicates that the transmission mechanisms of shocks in the related countries are similar. A correlation coefficient close to zero would indicate completely different transmission mechanisms, while a negative correlation coefficient would mean that the particular shock leads to a divergence of the cycles of the countries.

The reported coefficients in Table 3a imply that the response of output cycles to supply shocks is highly synchronised in the G7 countries, the lowest correlation coefficient being observed between the cycles of Canada and Italy with a reading of $0.81 .^{9}$ The transmission mechanisms also show important similarities in the face of demand shocks, albeit to a lesser extent than the transmission mechanisms of supply shocks. The relationships between Germany and the rest of the G7 countries are in this respect rather an exception with relatively weaker correlations. Finally, the output cycles would have usually also been rather highly correlated if common nominal shocks occurred in the sample period only, but less strongly than in the case of supply and demand shocks. France shows stark contrast in this respect compared to the other G7 countries, displaying weak or negative correlations with them. Common nominal shocks alone would have even led to a divergence between the output cycles of France and the United Kingdom.

The counterfactual correlations reported for inflation growth in Table $3 \mathrm{~b}$ are generally weaker than the correlations reported for output cycles. Although a reason behind this might be that inflation growth is high frequency data whereas output cycles refer to lower frequencies, lower correlations are still obtained if a cyclical component is computed for

\footnotetext{
${ }^{8}$ Recall that the supply, demand and nominal shocks of Japan are insignificantly related to common G7 shocks as reported in Table 2. Therefore, we do not comment the correlations corresponding to Japan in the following.

${ }^{9}$ Note that the strong correlation that would have occurred if only common supply shocks took place in the past does not immediately imply that those shocks have played a major role for the co-movements. We deal with the latter question with the aid of variance decompositions below.
} 
the inflation using the Christiano-Fitzgerald filter as for output (not reported here). The transmission mechanisms of common supply shocks on inflation growth have been different from country to country according to the reported correlations in Table 3b. Common demand or nominal shocks alone would have led, however, to generally high positive correlations, implying that the shock propagation mechanisms of the G7 countries are quite similar in this respect.

Nominal interest rate growth counterfactual correlations reported in Table 3c point, as in the case of output cycle counterfactual correlations, to similar dynamic response mechanisms in the G7 countries. Germany's nominal interest rate growth is here an exception, which would have diverged from the nominal interest rate growth in the other countries, had only common supply shocks occurred in the past.

Finally, it can be established by looking at the last panels of Tables 3a, 3b and 3c that, abstracting from Japan, we would have observed very high correlations of the G7 countries' cycles if all common shocks took place in past and country-specific shocks were absent.

\subsection{Historical Variance Decomposition}

\subsubsection{Entire Sample}

The counterfactual correlations of the previous sub-section show that rather high correlations would generally have been observed between the cyclical fluctuations of the G7 countries if they were subject to common shocks only. However, the true correlations between the cycles are generated by common as well as country-specific shocks, whereby the latter do not lead to any statistically significant correlation among the cycles by construction of our empirical model. Therefore, it is interesting to look at the weight of common and country-specific shocks in the fluctuations of the model variables. Obviously, if the common shocks have only a minor share in the variance of the cycles, it is unlikely that the true correlations of the cycles are high.

The reported shares in Table 4a show that in our sample period the variance of output cycles is explained in every G7 country mainly by supply shocks. The share of supply shocks has been particularly high in France, Germany, Japan and the United Kingdom. Italy differs 
from the other euro-area countries in this respect, with its output cycles being also partly attributable to nominal shocks like in Canada and the US. The US is the only country where demand shocks have contributed, albeit weakly, to output fluctuations. The share of the common component in output cycles is highest in France with 0.73, i.e., more than half of the variance of output cycles was due to common shocks in this country in the sample period. The output cycles of Germany and the United Kingdom were also driven to an important extent by common shocks to the G7 countries with shares of 0.30 and 0.35 , respectively. However, these shocks played a smaller role in the cycles of the rest of the G7 countries.

The reported shares of shocks in Table $4 \mathrm{~b}$ indicate that inflation dynamics are to a large extent driven by country-specific factors. Japan is the most extreme example here, for which the empirical model attributes the entire fluctuation in inflation growth to country-specific shocks. Also, among the G7 countries, Japan's supply shocks had the largest share (0.20) in the fluctuations of inflation growth. Supply shocks had small effects in the other G7 countries' inflation growth variance. Country-specific demand and nominal shocks had a rather balanced share in the inflation growth fluctuations of the euro area countries and Canada, while demand shocks were dominant in the United Kingdom with a share of 0.82 and nominal shocks were dominant in the US with a share of 0.81 .

The variance of nominal interest rate growth can be attributed to a moderate extent to common G7 shocks as in the case of output cycles, see Table 4c. The decomposition of the variance with respect to the structural shocks, however, differs significantly from the output cycle variance decomposition. Supply shocks have played a less important role in the variance of nominal interest rate growth, which has in turn been negligible in France, Germany and the UK. Demand shocks were the main determinant of the volatility in nominal interest rate growth in Germany and the US, while the nominal shocks contributed the most to the same volatility in Canada, France, Italy, Japan and the UK.

\subsubsection{6-Year Rolling Windows}

An important methodological advantage of the historical variance decomposition technique employed for estimating the shares reported in Tables $4 \mathrm{a}, 4 \mathrm{~b}$ and $4 \mathrm{c}$ is that it is applicable also to sub-periods. Therefore, we can use the technique for computing the shares 
of structural G7 shocks in the cycles of the countries over 6-year rolling windows. To do this, we first compute the realisations of cycles for each country with respect to each common and country-specific structural shock for the whole sample period. ${ }^{10}$ Hence, we obtain six sub-components (counterfactual components) of the cycles of each variable of each country for the whole sample period. The sum of these six components gives the true cycle. We then compute the variance of a country's related cycle in the first 6-year window from 1972Q2 to 1978Q1. The covariance of each counterfactual sub-component with the (corresponding) total cycle divided by the variance of the total cycle for the 6-year window gives then the estimate of the share of the shock corresponding to the sub-component. Then, the same computation is done for the second 6-year window from 1972Q3 to 1978Q2, etc.

Figure 2a illustrates the shares of common shocks in output fluctuations in the G7 countries. Common demand and nominal shocks have not played a considerable role in any of the countries throughout the entire sample period. Only in Canada and Italy had common nominal shocks a share of about 0.15 until the beginning of the 1990s. There have been, however, episodes where common supply shocks were an important determinant of output cycles. In particular, French output cycles have largely been driven by common supply shocks, the effect of which has decreased recently. These shocks were also an important driving force of output cycles until the early 1980s in Canada, Germany, Japan and the United Kingdom. The United Kingdom has seen an important surge in the share of common supply shocks after the mid-1990s, which has, however, disappeared within the short time period after 2005. Finally, common supply shocks have not been an important driving force of output cycles in the US throughout the sample period.

The picture arising from Figure 2a does partly help to explain the dynamics of mean correlations of the G7 output cycles presented in Figure 1. The decrease in the output cycle mean correlations from the beginning of the sample period until the mid-1990s in Figure 1 arises clearly from the gradual decreases in the share of common supply shocks in Germany, Japan and the United Kingdom observed in Figure 2a. Canada and the US have also shown abrupt decreases in the same share in the same period, the former in the first half of the

\footnotetext{
${ }^{10}$ This is done exactly as in the case of computing the counterfactual correlations above. However, the counterfactual correlations were computed with respect to common structural shocks only.
} 
1980s and the latter in the first half of the 1990s, which can also be roughly followed in Figure 1. Furthermore, the recent abrupt decrease in the mean correlations of the G7 countries' output cycles can be traced back to the decrease in the share of common supply shocks in the output cycle variance of France, Germany and the United Kingdom in particular, and, to a lesser extent, Italy and Japan.

Figure $2 \mathrm{~b}$, which shows the shares of common shocks in the inflation growth of the G7 countries, is also in line with the above result that refers to the entire sample period: common shocks had negligible effects in the past. The only exception in this respect is the surge in the share of common demand shocks in the inflation growth variance after 2000 in the United Kingdom, which, however, decreased again recently.

The role of common supply shocks in the nominal interest rate growth fluctuations has generally been rather low as illustrated in Figure 2c. Common supply shocks can be attributed an increasing share only in the fluctuations of France since about 2000. On the other hand, common demand shocks have played a gradually increasing role in the volatility of nominal interest rate growth of France, Germany and the US and recently became the dominant source of the fluctuations of this variable in those countries. Finally, common nominal shocks have a significant share in the nominal interest rate growth variance throughout our sample period, which is also in line with the reported shares in Table 4c, but are not so important for the same variance in the other G7 countries.

\section{Conclusions}

In this paper, we have investigated the properties of the G7 countries' business cycle dynamics, which are assumed to be driven by common supply, demand and nominal shocks. We found that output cycles of the G7 countries have generally been highly correlated in our entire sample as well as in shorter windows. Yet, a general increase in the business cycle synchronisation could not be established, as some studies have suggested, due to the factors such as increased trade, stronger financial market integration and other international institutions, etc. Nominal interest rate growth, though a higher-frequency variable than output cycle, was found to be also moderately correlated in the G7 group, for which a gradual increase in international synchronisation since the mid-1990s could be observed. 
Inflation growth, on the other hand, is a rather country-specific phenomenon according to our findings and has also been so in shorter windows in the past.

Our counterfactual analysis has pointed to the similarity of shock propagation mechanisms in the G7 countries in many cases. That is, we would have observed much higher correlations of the cyclical measures in our study, if only common shocks had occurred or if common shocks had a larger share in the variance of the cycles/growth rates of the G7 countries. Japan is, however, an important exception in this respect. None of its estimated country-specific structural shocks is significantly related to the common G7 component. Furthermore, in line with this finding, the common G7 shocks contribute the least to the variance of the Japanese cycle and growth rates among the G7 countries. The latter finding has likely to do with the de-coupling of Japan from the other G7 economics after the 1990s. This is evident in our estimated common-supply-shock shares in the output cycles of Japan over 6-year rolling windows, which have been around zero since the second half of the 1990s. Other studies confirm this conclusion, too. Stock and Watson (2005) write, for example, that "during the 1980s and 1990s, the cyclical fluctuations in Japanese GDP became almost detached from the other G7 economies, with domestic shocks explaining almost all of the cyclical movements in Japanese GDP". Their forecast error variance decomposition (FEVD) analysis shows that 20 percent of output growth forecast error variance of Japan could be attributed to G7 shocks in the sample 1960-1983, while that share decreased to 1 percent in the sample 1984-2002 at a forecast horizon of 8 quarters. The findings of Perez et al. (2006), who estimate US, EU15 and country-specific shocks for each G7 country, do also roughly confirm this result.

The historical variance decomposition attributes 72 percent of the variance of France's output cycles to common supply shocks, which is by far the highest share observed among the G7 countries. While this irregularity deserves to be scrutinised in the future, we would like to note that it is not a finding peculiar to our study. The FEVD carried out by Stock and Watson (2005) attributes shares as high as 87 and 88 percent to the G7 shocks in the output growth forecast error variance of France at a forecast horizon of 8 quarters in the samples from 1960-1983 and from 1984-2002, respectively. Crucini et al. (2008) also obtain that G7 shocks have the highest share (80 percent) in output growth variance of France 
among the G7 countries. Finally, the country-specific shocks have only a limited share in the output growth variance of France, while US and (even much more) EU15 shocks have large weights in that variance according to the findings of Perez et al. (2006). Note that there are important differences between our empirical approach and the empirical approach of the aforementioned studies. For example, we do not measure spillover effects, or our model does not include euro area shocks. Yet, the variance of French output cycles being determined primarily by sources outside the economy seems to be a result common to all those studies.

Common nominal shocks contribute to the output cycle variance in Canada, Italy and the US and common demand shocks in the US, albeit with a very small share, and the weights of nominal and demand shocks were negligible for all other G7 countries according to our findings. The total share of common shocks in the inflation growth variance could exceed 15 percent only in the case of Germany and the UK, with 18 and 15 percent, respectively, which explains the low international correlation coefficients corresponding to this variable. Obviously, the G7 countries do not differ much in terms of shock propagation with respect to inflation growth, but they are subject to large asymmetric shocks. Finally, the total share of common shocks is quite high in the G7 countries' nominal interest rate growth, except in Japan. Together with generally high-estimated counterfactual correlations, this finding explains the strong correlation among the G7 countries' nominal interest rate growth.

The empirical model we employ is in line with a class of theoretical international business cycle models, which trace international linkages back to exogenous shocks. The main advantage of our empirical approach vis-à-vis other empirical approaches followed in the related literature is that it enables us to classify common and country-specific shocks and their dynamic effects on the economy from a structural point of view. In order to be able to estimate structural common and country-specific shocks, we simplify our setting by assuming that countries interact through exogenous shocks only. The current setting does not allow us to deal with the impact of bilateral spillovers. The next step in our research agenda is to deal with this issue.

Another challenge is to take the interdependencies of the endogenous variables into account. There are two main problems to deal with in this context. First, the number of parameters to estimate explodes in VAR models including many countries. Second, the 
identification of structural shocks becomes a more difficult issue. Although a recent literature (initiated by Dees et al. (2007) among others) allows to model the world in a global vector autoregression (GVAR) framework in a convenient way, the structural identification in this framework still poses a challenge for macroeconometricians. The research in this area could be another natural extension of our paper.

\section{References}

Artis M. Should the UK Join EMU? National Institute Economic Review 2000; 171: 70-81.

Backus BK, Kehoe PJ, Kydland FE. International Real Business Cycles. The Journal of Political Economy 1992; 100: 745-775.

Baxter M, Crucini MJ. Explaining Saving-Investment Correlations. The American Economic Review 1993; 83: 416-436.

Bayoumi T, Eichengreen B. Shocking Aspects of European Monetary Unification. NBER Working Paper 1992; No. 3949.

Blanchard OJ, Quah D. The Dynamic Effects of Aggregate Demand and Supply Disturbances. The American Economic Review 1989; 79: 655-673.

Canova F, Ciccareli M, Ortega E. Similarities and Convergence in G-7 Cycles. Journal of Monetary Economics 2007; 54: 850-878.

Chamie N, DeSerres A, Lalonde R. Optimum Currency Areas and Shock Asymmetry: A Comparison of Europe and the United States. Bank of Canada Working Paper 1994; No. $94-1$.

Christiano LJ, Fitzgerald TJ. The Band Pass Filter. International Economic Review 2003; 44: 435-465.

Crucini MJ, Kose MA, Otrok C. What Are the Driving Forces of International Business Cycles. NBER Working Paper 2008; No. 14380. 
Dees S, di Mauro F, Pesaran MH, Smith LV. Exploring the International Linkages of the Euro Area: A Global Var Analysis. Journal of Applied Econometrics 2007; 22: 1-38.

Fidrmuc J, Korhonen I. Similarity of Supply and Demand Shocks Between the Euro Area and the CEECs. Economic Systems 2003; 27: 313-336.

Frenkel M, Nickel C. How Symmetric are the Shocks and the Shock Adjustment Dynamics between the Euro Area and Central and Eastern European Countries. Journal of Common Market Studies 2005; 43: 53-74.

King R, Plosser C, Stock J, Watson M. Stochastic Trends and Economic Fluctuations. The American Economic Review 1991; 81:819-840.

Perez PJ, Osborn DR, Artis M. The International Business Cycle in a Changing World: Volatility and the Propagation of Shocks in the G-7. Open Economics Review 2006; 17: 255-279.

Stock JH, Watson MW. Understanding Changes in International Business Cycle Dynamics. Journal of the European Economic Association 2005; 3: 968-1006.

Seymen A. A Critical Note on the Forecast Error Variance Decomposition. ZEW Discussion Paper 2008; No. 08-065.

Xu X. A Currency Union for Hong Kong and Mainland China? Journal of International Money and Finance 2006; 25: 894-911. 
Table 1: Correlation among cyclical components of the variables across countries

\begin{tabular}{|c|c|c|c|c|c|c|c|}
\hline & \multicolumn{7}{|c|}{ Output cycle } \\
\hline & can & fra & ger & ita & jap & $\mathrm{uk}$ & us \\
\hline can & 1.00 & & & & & & \\
\hline fra & 0.44 & 1.00 & & & & & \\
\hline ger & 0.32 & 0.52 & 1.00 & & & & \\
\hline ita & 0.57 & 0.73 & 0.58 & 1.00 & & & \\
\hline jap & 0.12 & 0.37 & 0.59 & 0.33 & 1.00 & & \\
\hline uk & 0.45 & 0.65 & 0.43 & 0.41 & 0.39 & 1.00 & \\
\hline us & 0.61 & 0.41 & 0.54 & 0.30 & 0.32 & 0.55 & 1.00 \\
\hline \multicolumn{8}{|c|}{ Inflation growth } \\
\hline & can & fra & ger & ita & jap & $\mathrm{uk}$ & us \\
\hline can & 1.00 & & & & & & \\
\hline fra & -0.19 & 1.00 & & & & & \\
\hline ger & -0.06 & 0.03 & 1.00 & & & & \\
\hline ita & 0.19 & -0.08 & 0.25 & 1.00 & & & \\
\hline jap & -0.06 & -0.05 & 0.01 & 0.09 & 1.00 & & \\
\hline $\mathrm{uk}$ & -0.07 & 0.30 & 0.11 & -0.08 & -0.06 & 1.00 & \\
\hline us & 0.28 & -0.08 & 0.13 & 0.03 & -0.07 & 0.06 & 1.00 \\
\hline & \multicolumn{7}{|c|}{ "Nominal interest rate growth } \\
\hline & can & fra & ger & ita & jap & $\mathrm{uk}$ & us \\
\hline can & 1.00 & & & & & & \\
\hline fra & 0.43 & 1.00 & & & & & \\
\hline ger & 0.45 & 0.45 & 1.00 & & & & \\
\hline ita & 0.27 & 0.41 & 0.18 & 1.00 & & & \\
\hline jap & 0.04 & 0.30 & 0.17 & 0.07 & 1.00 & & \\
\hline $\mathrm{uk}$ & 0.24 & 0.30 & 0.29 & 0.27 & 0.37 & 1.00 & \\
\hline us & 0.69 & 0.36 & 0.35 & 0.29 & -0.08 & 0.20 & 1.00 \\
\hline
\end{tabular}

Notes: The cyclical component of output is computed using the filter suggested by Christiano and Fitzgerald (2003), where the business cycle horizon is assumed to be in the time period from 6 to 32 quarters. The cyclical measure for the inflation and the nominal interest rate is the quarterly growth. The sample period is from 1972:2-2007:4, see the text. 
Table 2: Estimated $\alpha$ coefficients

\begin{tabular}{cccccccc}
\hline \hline \multirow{5}{*}{ supply } & can & fra & ger & ita & jap & uk & us \\
& 0.58 & 1.71 & 1.13 & 0.49 & 0.41 & 0.92 & 0.68 \\
demand & $(0.01)$ & $(0.00)$ & $(0.00)$ & $(0.07)$ & $(0.15)$ & $(0.00)$ & $(0.01)$ \\
& 0.75 & 0.89 & 1.19 & 0.71 & -0.41 & 0.96 & 1.55 \\
\multirow{5}{*}{ nominal } & $(0.00)$ & $(0.00)$ & $(0.00)$ & $(0.00)$ & $(0.26)$ & $(0.00)$ & $(0.00)$ \\
& 0.82 & 0.84 & 0.79 & 1.25 & 0.33 & 1.49 & 0.49 \\
& $(0.00)$ & $(0.00)$ & $(0.00)$ & $(0.00)$ & $(0.21)$ & $(0.00)$ & $(0.07)$ \\
\hline
\end{tabular}

Notes: $p$-values in parantheses. $\alpha$ coefficients refer to the coefficients for the individual countries that correspond to the common components of the structural shocks -supply, demand and nominal- in (3). 
Table 3a: Counterfactual correlations of output cycles of G7 countries with respect to the common component of structural shocks

\begin{tabular}{|c|c|c|c|c|c|c|c|}
\hline & \multicolumn{7}{|c|}{ Supply } \\
\hline & can & fra & ger & ita & jap & $\mathrm{uk}$ & us \\
\hline can & 1.00 & & & & & & \\
\hline fra & 0.93 & 1.00 & & & & & \\
\hline ger & 0.84 & 0.97 & 1.00 & & & & \\
\hline ita & 0.81 & 0.96 & 0.97 & 1.00 & & & \\
\hline jap & 0.97 & 0.99 & 0.94 & 0.92 & 1.00 & & \\
\hline $\mathrm{uk}$ & 0.92 & 1.00 & 0.98 & 0.96 & 0.99 & 1.00 & \\
\hline \multirow[t]{3}{*}{ us } & 0.98 & 0.99 & 0.93 & 0.90 & 1.00 & 0.98 & 1.00 \\
\hline & \multicolumn{7}{|c|}{ Demand } \\
\hline & can & fra & ger & ita & jap & $\mathrm{uk}$ & us \\
\hline can & 1.00 & & & & & & \\
\hline fra & 0.96 & 1.00 & & & & & \\
\hline ger & 0.45 & 0.64 & 1.00 & & & & \\
\hline ita & 0.91 & 0.88 & 0.26 & 1.00 & & & \\
\hline jap & 0.90 & 0.94 & 0.77 & 0.70 & 1.00 & & \\
\hline uk & 0.92 & 0.99 & 0.72 & 0.85 & 0.94 & 1.00 & \\
\hline us & 0.99 & 0.99 & 0.54 & 0.90 & 0.93 & 0.96 & 1.00 \\
\hline
\end{tabular}

\begin{tabular}{|c|c|c|c|c|c|c|c|}
\hline & \multicolumn{7}{|c|}{ Nominal } \\
\hline & can & fra & ger & ita & jap & $\mathrm{uk}$ & us \\
\hline can & 1.00 & & & & & & \\
\hline fra & 0.07 & 1.00 & & & & & \\
\hline ger & 0.93 & -0.15 & 1.00 & & & & \\
\hline ita & 0.86 & -0.11 & 0.81 & 1.00 & & & \\
\hline jap & 0.71 & -0.47 & 0.81 & 0.90 & 1.00 & & \\
\hline uk & 0.78 & -0.54 & 0.85 & 0.85 & 0.94 & 1.00 & \\
\hline \multirow[t]{3}{*}{ us } & 0.98 & 0.27 & 0.86 & 0.78 & 0.57 & 0.64 & 1.00 \\
\hline & & & & All & & & \\
\hline & can & fra & ger & ita & jap & $\mathrm{uk}$ & us \\
\hline can & 1.00 & & & & & & \\
\hline fra & 0.90 & 1.00 & & & & & \\
\hline ger & 0.86 & 0.97 & 1.00 & & & & \\
\hline ita & 0.83 & 0.89 & 0.92 & 1.00 & & & \\
\hline jap & 0.94 & 0.99 & 0.96 & 0.89 & 1.00 & & \\
\hline uk & 0.91 & 0.97 & 0.98 & 0.93 & 0.98 & 1.00 & \\
\hline us & 0.89 & 0.86 & 0.87 & 0.87 & 0.87 & 0.88 & 1.00 \\
\hline
\end{tabular}


Table 3b: Counterfactual correlations of inflation growth of G7 countries with respect to the common component of structural shocks

\begin{tabular}{cccccccc}
\hline \hline \multicolumn{8}{c}{ Supply } \\
\hline & can & fra & ger & ita & jap & uk & us \\
\hline can & 1.00 & & & & & & \\
fra & 0.06 & 1.00 & & & & & \\
ger & 0.44 & -0.22 & 1.00 & & & & \\
ita & 0.04 & -0.10 & 0.43 & 1.00 & & & \\
jap & 0.03 & -0.18 & -0.05 & -0.37 & 1.00 & & \\
uk & 0.39 & -0.25 & 0.77 & 0.11 & 0.57 & 1.00 & \\
us & -0.28 & -0.45 & 0.31 & -0.03 & 0.74 & 0.68 & 1.00 \\
\hline
\end{tabular}

\begin{tabular}{cccccccc}
\hline \hline \multicolumn{8}{c}{ Demand } \\
\hline & can & fra & ger & ita & jap & uk & us \\
\hline can & 1.00 & & & & & & \\
fra & 0.92 & 1.00 & & & & & \\
ger & 0.82 & 0.68 & 1.00 & & & & \\
ita & 0.86 & 0.82 & 0.85 & 1.00 & & & \\
jap & -0.79 & -0.75 & -0.79 & -0.92 & 1.00 & & \\
uk & 0.97 & 0.87 & 0.86 & 0.90 & -0.90 & 1.00 & \\
us & 0.67 & 0.56 & 0.77 & 0.61 & -0.78 & 0.77 & 1.00 \\
\hline
\end{tabular}

\begin{tabular}{|c|c|c|c|c|c|c|c|}
\hline & \multicolumn{7}{|c|}{ Nominal } \\
\hline & can & fra & ger & ita & jap & $\mathrm{uk}$ & us \\
\hline can & 1.00 & & & & & & \\
\hline fra & 0.99 & 1.00 & & & & & \\
\hline ger & 0.80 & 0.83 & 1.00 & & & & \\
\hline ita & 0.97 & 0.97 & 0.91 & 1.00 & & & \\
\hline jap & 0.74 & 0.69 & 0.35 & 0.64 & 1.00 & & \\
\hline uk & 0.67 & 0.65 & 0.35 & 0.63 & 0.83 & 1.00 & \\
\hline \multirow[t]{3}{*}{ us } & 0.90 & 0.90 & 0.93 & 0.95 & 0.60 & 0.63 & 1.00 \\
\hline & & & & $\overline{~ A l l}$ & & & \\
\hline & can & fra & ger & ita & jap & $\mathrm{uk}$ & us \\
\hline can & 1.00 & & & & & & \\
\hline fra & 0.82 & 1.00 & & & & & \\
\hline ger & 0.76 & 0.59 & 1.00 & & & & \\
\hline ita & 0.87 & 0.81 & 0.80 & 1.00 & & & \\
\hline jap & -0.21 & -0.12 & -0.18 & -0.18 & 1.00 & & \\
\hline uk & 0.75 & 0.50 & 0.63 & 0.61 & -0.19 & 1.00 & \\
\hline us & 0.68 & 0.55 & 0.76 & 0.71 & 0.03 & 0.62 & 1.00 \\
\hline
\end{tabular}


Table 3c: Counterfactual correlations of nominal interest rate growth of G7 countries with respect to the common component of structural shocks

\begin{tabular}{cccccccc}
\hline \hline \multicolumn{7}{c}{ Supply } \\
\hline & can & fra & ger & ita & jap & uk & us \\
\hline can & 1.00 & & & & & & \\
fra & 0.40 & 1.00 & & & & & \\
ger & -0.23 & 0.59 & 1.00 & & & & \\
ita & 0.80 & 0.65 & 0.06 & 1.00 & & & \\
jap & 0.74 & 0.02 & -0.55 & 0.35 & 1.00 & & \\
uk & 0.73 & 0.64 & -0.09 & 0.88 & 0.42 & 1.00 & \\
us & 0.87 & 0.06 & -0.32 & 0.57 & 0.63 & 0.49 & 1.00 \\
\hline
\end{tabular}

\begin{tabular}{cccccccc}
\hline \hline \multicolumn{7}{c}{ Demand } \\
\hline & can & fra & ger & ita & jap & uk & us \\
\hline can & 1.00 & & & & & & \\
fra & 0.98 & 1.00 & & & & & \\
ger & 0.88 & 0.95 & 1.00 & & & & \\
ita & 0.96 & 0.97 & 0.91 & 1.00 & & & \\
jap & -0.96 & -0.98 & -0.91 & -0.95 & 1.00 & & \\
uk & 0.76 & 0.84 & 0.94 & 0.79 & -0.84 & 1.00 & \\
us & 0.94 & 0.93 & 0.80 & 0.89 & -0.95 & 0.74 & 1.00 \\
\hline
\end{tabular}

\begin{tabular}{cccccccc}
\hline \hline \multicolumn{7}{c}{ Nominal } \\
\hline & can & fra & ger & ita & jap & uk & us \\
\hline can & 1.00 & & & & & & \\
fra & 0.97 & 1.00 & & & & & \\
ger & 0.97 & 0.91 & 1.00 & & & & \\
ita & 0.99 & 0.97 & 0.95 & 1.00 & & & \\
jap & 0.95 & 0.88 & 0.95 & 0.91 & 1.00 & & \\
uk & 0.97 & 0.99 & 0.91 & 0.98 & 0.88 & 1.00 & \\
us & 0.85 & 0.73 & 0.87 & 0.76 & 0.89 & 0.74 & 1.00 \\
\hline \multicolumn{7}{c}{} & \multicolumn{7}{c}{ All } & & & \\
\hline \hline & can & fra & ger & ita & jap & uk & us \\
\hline can & 1.00 & \multicolumn{7}{c}{} & & & & \\
fra & 0.87 & 1.00 & & & & & \\
ger & 0.79 & 0.88 & 1.00 & & & & \\
ita & 0.92 & 0.87 & 0.77 & 1.00 & & & \\
jap & 0.41 & 0.13 & -0.10 & 0.38 & 1.00 & & \\
uk & 0.90 & 0.86 & 0.73 & 0.98 & 0.42 & 1.00 & \\
us & 0.70 & 0.66 & 0.74 & 0.51 & -0.18 & 0.46 & 1.00 \\
\hline
\end{tabular}


Table 4a: Shares of shocks in output fluctuations of G7 countries

\begin{tabular}{c|cccc|ccc}
\hline \hline & \multicolumn{4}{|c|}{ Common } & \multicolumn{3}{c}{ Total } \\
\hline & supply & demand & nominal & total & supply & demand & nominal \\
\hline can & 0.11 & 0.02 & 0.08 & 0.21 & 0.71 & 0.02 & 0.26 \\
fra & 0.72 & 0.01 & 0.00 & 0.73 & 0.97 & 0.03 & -0.00 \\
ger & 0.27 & 0.01 & 0.02 & 0.30 & 0.90 & 0.03 & 0.06 \\
ita & 0.13 & 0.00 & 0.10 & 0.23 & 0.81 & 0.01 & 0.19 \\
jap & 0.13 & 0.00 & 0.01 & 0.14 & 0.96 & 0.01 & 0.03 \\
uk & 0.29 & 0.00 & 0.05 & 0.35 & 0.92 & 0.00 & 0.08 \\
us & 0.11 & 0.07 & 0.02 & 0.20 & 0.67 & 0.13 & 0.20 \\
\hline
\end{tabular}

Table 4b: Shares of shocks in inflation growth of G7 countries

\begin{tabular}{c|cccc|ccc}
\hline \hline & \multicolumn{4}{|c|}{ Common } & \multicolumn{3}{c}{ Total } \\
\hline & supply & demand & nominal & total & supply & demand & nominal \\
\hline can & 0.00 & 0.00 & 0.05 & 0.05 & 0.02 & 0.64 & 0.33 \\
fra & 0.03 & 0.05 & 0.02 & 0.11 & 0.05 & 0.44 & 0.51 \\
ger & 0.02 & 0.10 & 0.06 & 0.18 & 0.09 & 0.44 & 0.47 \\
ita & 0.00 & 0.05 & 0.08 & 0.13 & 0.03 & 0.66 & 0.31 \\
jap & -0.01 & 0.00 & 0.01 & 0.00 & 0.20 & 0.55 & 0.25 \\
uk & 0.03 & 0.08 & 0.04 & 0.15 & 0.11 & 0.82 & 0.07 \\
us & -0.00 & 0.05 & 0.05 & 0.10 & 0.09 & 0.10 & 0.81 \\
\hline
\end{tabular}

Table 4c: Shares of shocks in nominal interest rate growth of G7 countries

\begin{tabular}{c|cccc|ccc}
\hline \hline & \multicolumn{5}{|c|}{ Common } & \multicolumn{3}{c}{ Total } \\
\hline & supply & demand & nominal & total & supply & demand & nominal \\
\hline can & 0.01 & 0.08 & 0.09 & 0.18 & 0.26 & 0.20 & 0.54 \\
fra & 0.06 & 0.09 & 0.12 & 0.26 & 0.08 & 0.40 & 0.52 \\
ger & 0.03 & 0.19 & 0.08 & 0.31 & 0.08 & 0.56 & 0.36 \\
ita & 0.02 & 0.02 & 0.23 & 0.27 & 0.24 & 0.04 & 0.71 \\
jap & 0.02 & 0.00 & 0.03 & 0.05 & 0.20 & 0.22 & 0.58 \\
uk & 0.04 & 0.02 & 0.34 & 0.40 & 0.14 & 0.05 & 0.81 \\
us & 0.01 & 0.31 & 0.02 & 0.33 & 0.18 & 0.67 & 0.15 \\
\hline
\end{tabular}



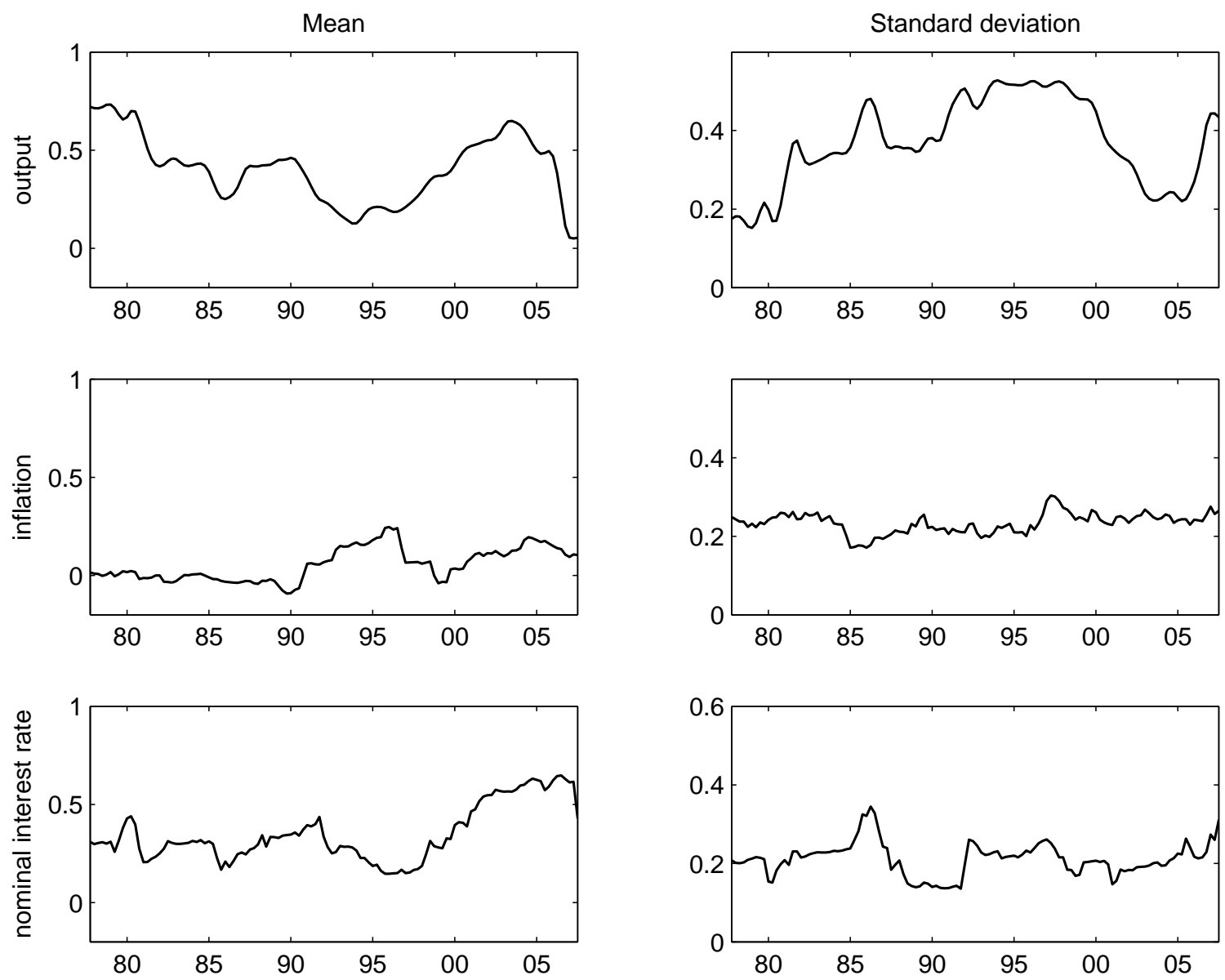

Figure 1: Mean and standard deviation of correlations of output cycles, and inflation and nominal interest rate growth among the G7 countries over a 6-year rolling window 
can

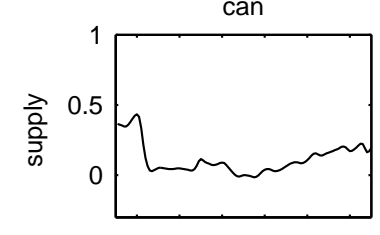

$80 \quad 8590950005$

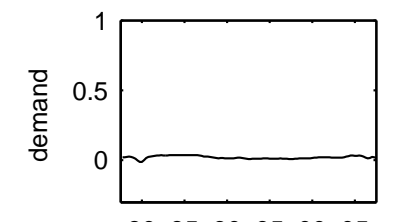

$80 \quad 8590950005$

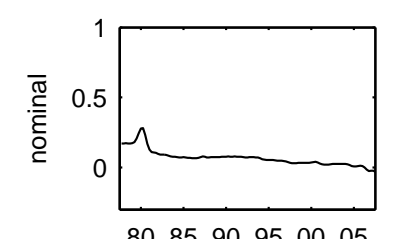

$80 \quad 8590950005$

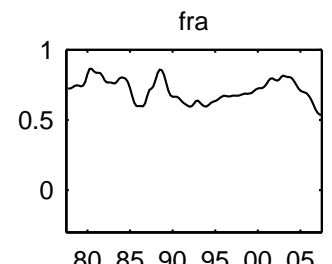

$\begin{array}{llllll}80 & 85 & 95 & 00 & 05\end{array}$

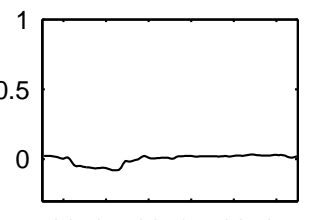

$80 \quad 8590950005$

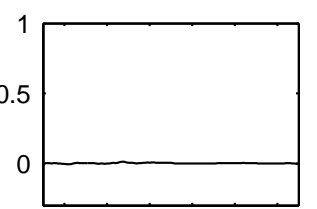

$80 \quad 8590 \quad 9500 \quad 05$

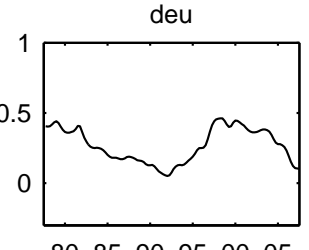

$\begin{array}{llllll}80 & 90 & 95 & 00 & 05\end{array}$

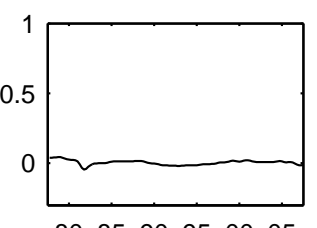

808590950005

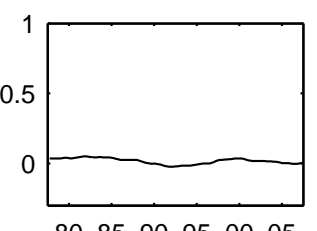

$80 \quad 8590 \quad 9500 \quad 05$ ita

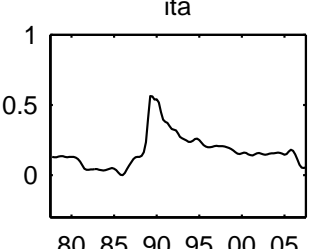

$80 \quad 85909500 \quad 05$

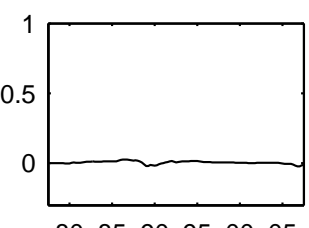

$80 \quad 859095 \quad 00 \quad 05$

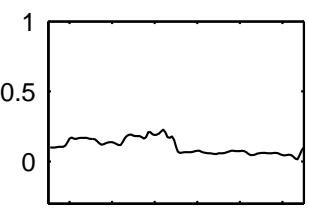

$80 \quad 859095 \quad 0005$

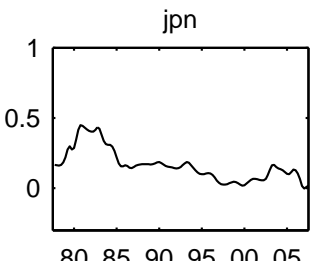

$80 \quad 85909500 \quad 05$

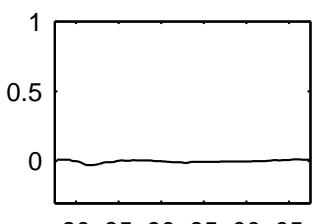

$80 \quad 859095 \quad 0005$

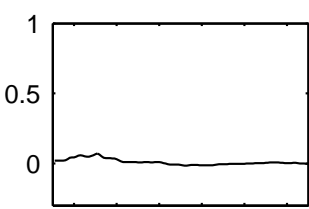

$80 \quad 8590 \quad 95 \quad 00 \quad 05$

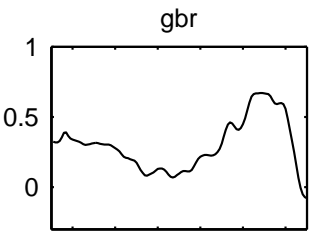

$80 \quad 859095 \quad 0005$

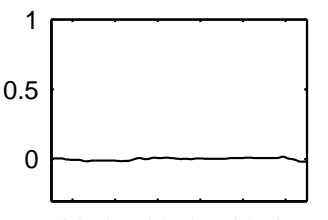

$80 \quad 859095 \quad 00 \quad 05$

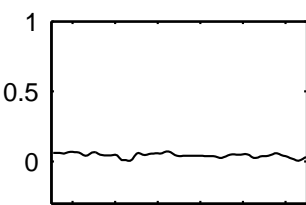

$80 \quad 8590 \quad 9500 \quad 05$
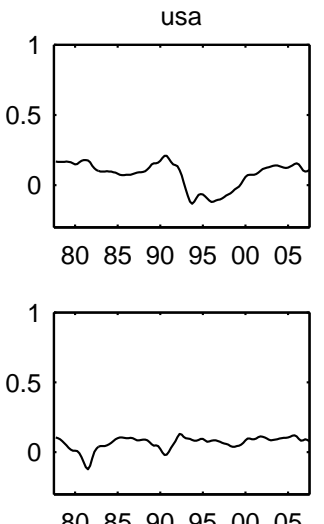

$80 \quad 859095 \quad 0005$

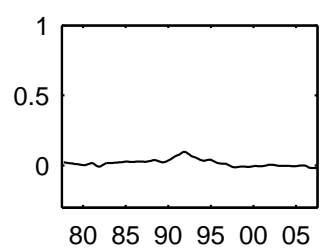

Figure 2a: Shares of common components of shocks in output cycle variance of G7 countries over a 6-year rolling window 
can

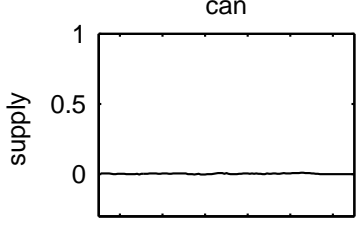

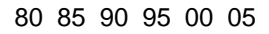

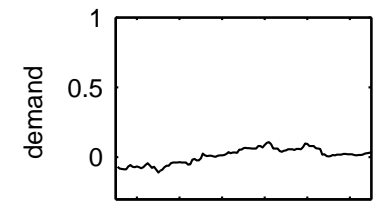

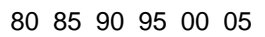

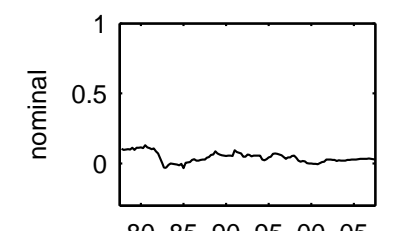

808590950005 fra

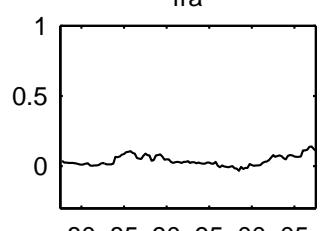

$80 \quad 85909500 \quad 05$

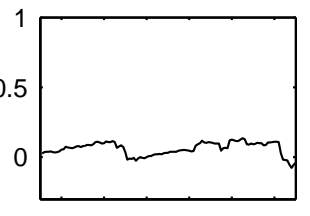

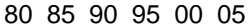

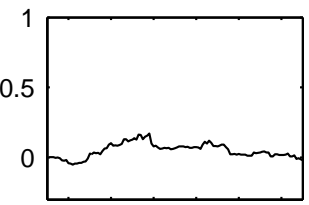

$80 \quad 8590 \quad 9500 \quad 05$ deu

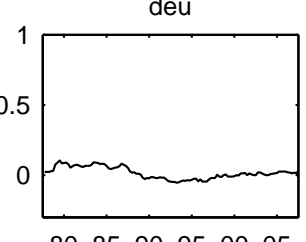

$80 \quad 8590 \quad 95 \quad 00 \quad 05$

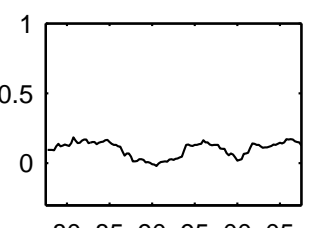

$80 \quad 859095 \quad 00 \quad 05$

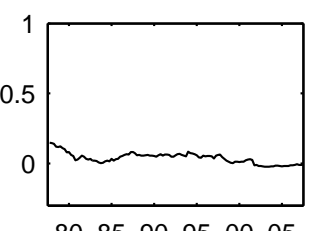

$\begin{array}{llllll}80 & 90 & 95 \quad 00 & 05\end{array}$ ita

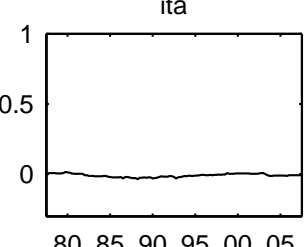

$80 \quad 8590 \quad 9500 \quad 05$

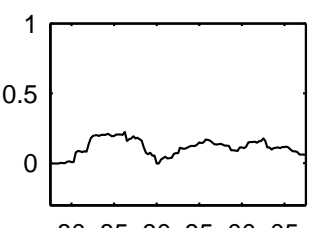

$80 \quad 8590 \quad 9500 \quad 05$

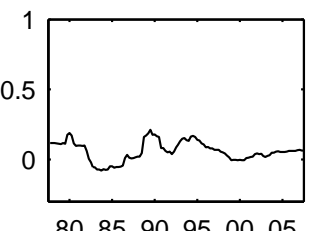

jpn

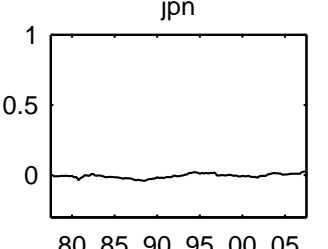

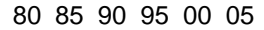

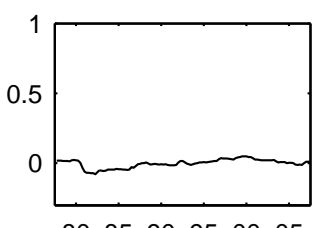

$80 \quad 8590950005$

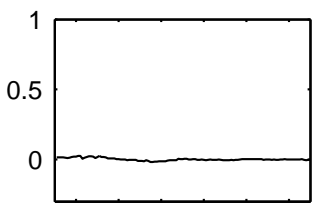

$80 \quad 8590 \quad 9500 \quad 05$

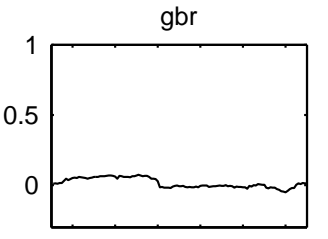

$80 \quad 859095 \quad 0005$

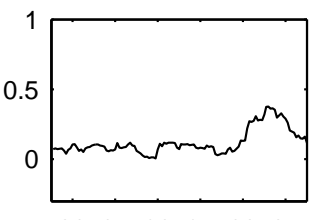

$80 \quad 8590 \quad 9500 \quad 05$

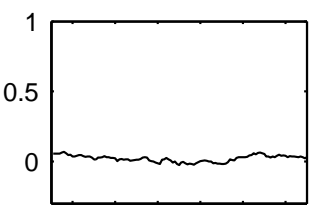

$80 \quad 8590 \quad 95 \quad 0005$ usa
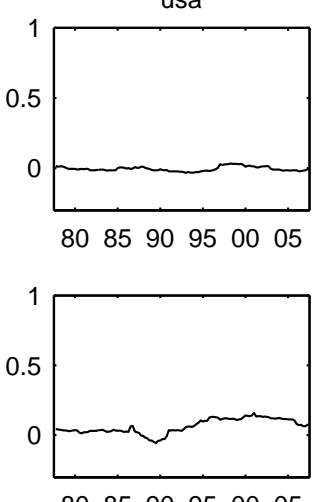

$\begin{array}{lllll}80 & 90 & 95 & 00 & 05\end{array}$

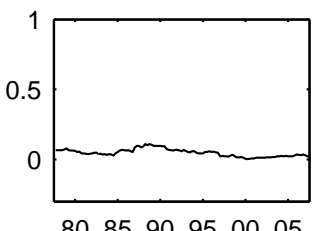

Figure 2b: Shares of common components of shocks in inflation growth variance of G7 countries over a 6-year rolling window 


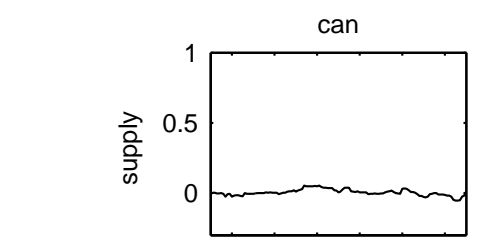

$80 \quad 8590950005$

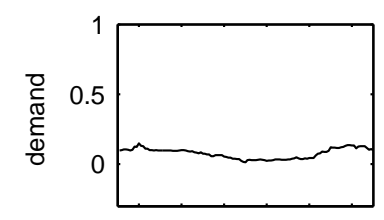

$80 \quad 8590950005$

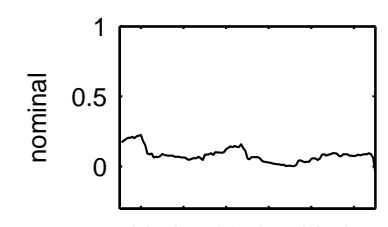

$80 \quad 8590 \quad 95 \quad 00 \quad 05$

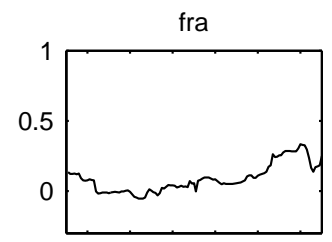

$80 \quad 8590950005$

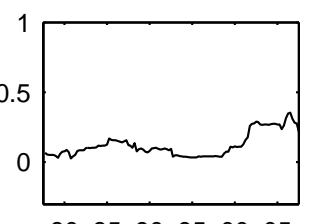

$80 \quad 859095 \quad 0005$

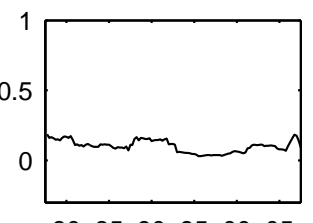

$80 \quad 8590950005$

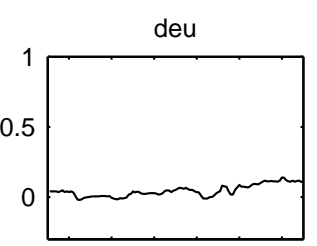

$80 \quad 85909500 \quad 05$

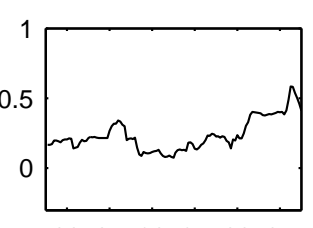

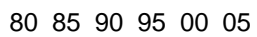

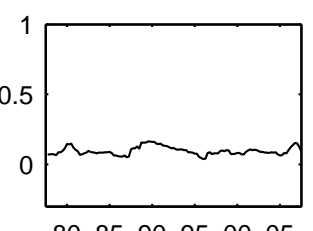

$80 \quad 859095 \quad 00 \quad 05$

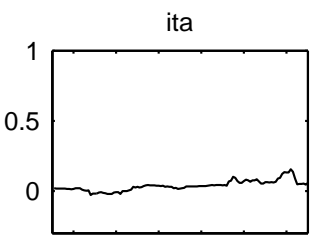

$8085909500 \quad 05$

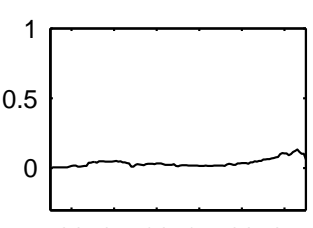

$80 \quad 8590950005$

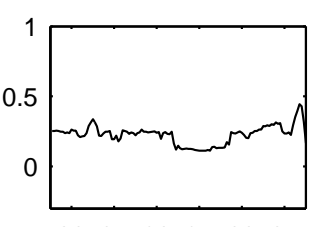

$80 \quad 859095 \quad 00 \quad 05$

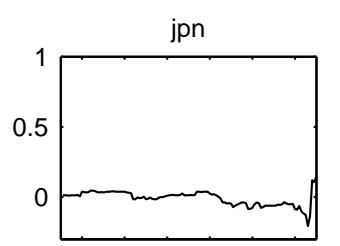

$\begin{array}{llllll}80 & 85 & 90 & 95 & 00 & 05\end{array}$

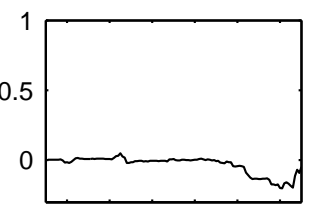

808590950005

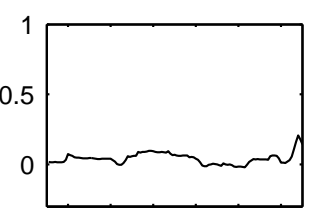

$80 \quad 859095 \quad 00 \quad 05$

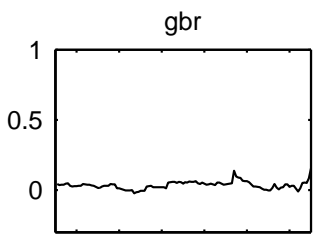

808590950005

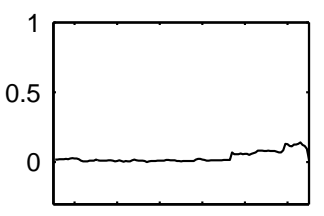

808590950005

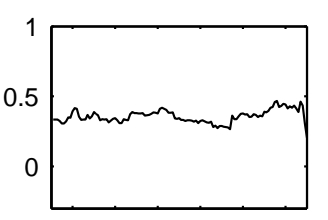

$80 \quad 859095 \quad 00 \quad 05$

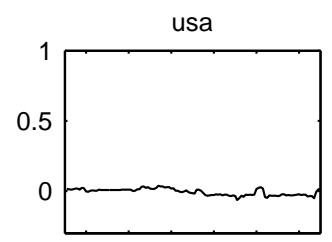

$80 \quad 85909500 \quad 05$

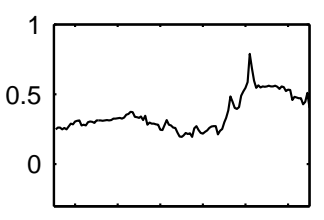

$80 \quad 85909500 \quad 05$

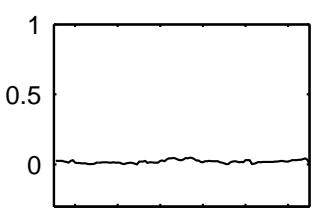

808590950005

Figure 2c: Shares of common components of shocks in nominal interest rate growth variance of G7 countries over a 6-year rolling window 